Article

\title{
Biosurfactants Induce Antimicrobial Peptide Production through the Activation of TmSpatzles in Tenebrio molitor
}

\author{
Tariku Tesfaye Edosa ${ }^{1,2,+} \mathbb{C}$, Yong Hun Jo $\left.{ }^{1,+} \mathbb{(}\right)$, Maryam Keshavarz ${ }^{1} \mathbb{C}$, In Seon Kim ${ }^{3}$ \\ and Yeon Soo Han $2, *$ (D) \\ 1 Department of Applied Biology, Institute of Environmentally-Friendly Agriculture (IEFA), \\ College of Agriculture and Life Sciences, Chonnam National University, Gwangju 61186, Korea; \\ bunchk.2000@gmail.com (T.T.E.); yhun1228@jnu.ac.kr (Y.H.J.); mariakeshavarz1990@gmail.com (M.K.) \\ 2 Ethiopian Institute of Agricultural Research, Ambo Agricultural Research Center, Ambo 37, Ethiopia \\ 3 Department of Agricultural Chemistry, College of Agriculture and Life Sciences, \\ Chonnam National University, Gwangju 61186, Korea; mindzero@chonnam.ac.kr \\ * Correspondence: hanys@jnu.ac.kr; Tel.: +82-62-530-2072 \\ + These authors contributed equally to this work.
}

Received: 13 July 2020; Accepted: 20 August 2020; Published: 24 August 2020

\begin{abstract}
Biosurfactant immunomodulatory activities in mammals, nematodes, and plants have been investigated. However, the immune activation property of biosurfactants in insects has not been reported. Therefore, here, we studied the defense response triggered by lipopeptides (fengycin and iturin A), glycolipids (rhamnolipid), and cyclic polypeptides (bacitracin) in the coleopteran insect, mealworm Tenebrio molitor. The in vitro antimicrobial activities against Gram-positive (Staphylococcus aureus) and Gram-negative (Escherichia coli) bacteria and fungi (Candida albicans) were assessed by mixing these pathogens with the hemolymph of biosurfactant-immune-activated larvae. E. coli growth was remarkably inhibited by this hemolymph. The antimicrobial peptide (AMP) induction results also revealed that all biosurfactants tested induced several AMPs, exclusively in hemocytes. The survivability analysis of T. molitor larvae challenged by E. coli $\left(10^{6} \mathrm{CFU} / \mu \mathrm{L}\right)$ at $24 \mathrm{~h}$ post biosurfactant-immune activation showed that fengycin, iturin A, and rhamnopid significantly increased survivability against E. coli. Biosurfactant-induced TmSpatzles activation was also monitored, and the results showed that TmSpz3 and TmSpz-like were upregulated in the hemocytes of iturin A-injected larvae, while TmSpz4 and TmSpz6 were upregulated in the fat bodies of the fengycin-, iturin A-, and rhamnolipid-injected larvae. Overall, these results suggest that lipopeptide and glycolipid biosurfactants induce the expression of AMPs in T. molitor via the activation of spätzle genes, thereby increasing the survivability of T. molitor against E. coli.
\end{abstract}

Keywords: antimicrobial peptides; biosurfactants; glycolipids; immunity; lipopeptides; mealworm; TmSpatzle

\section{Introduction}

Biosurfactants are surface-active biomolecules containing hydrophobic and hydrophilic moieties that are produced by bacteria, fungi, and yeast [1]. Unlike chemically synthesized surfactants, biosurfactants are generally categorized based on their microbial origin and chemical composition [2]. Chemically, biosurfactants are categorized into glycolipids (rhamnolipids) [3], trehalolipids [4], sophorolipids [5], lipopeptides and lipoproteins (surfactin, fengycine, and iturin), fatty acids, phospholipids and neutral lipids [5], polymeric, and particulate biosurfactants [6]. 
Owing to their safe properties, such as their low toxicity [7], high degree of biodegradability [8], high foaming capacity [9], and optimal activity under extreme environmental conditions [10], biosurfactants have received recent attention for their different applications in various fields, including medicine, food, bioremediation of toxic pollutants, and biopesticides.

The application of biosurfactants in agriculture has been repeatedly reported in plant disease control (as they exhibit antifungal and antibacterial activity [11,12]) and plant growth promotion [13]. More specifically, lipopeptide biosurfactants exhibit growth inhibition of phytopathogenic fungi, like Fusarium spp., Aspergillus spp., and Biopolaris sorokiniana [14]. Moreover, lipopeptides isolated from Brevibacilis brevis have demonstrated strong antibacterial and antifungal properties [15]. Interestingly, rhamnolipid showed the ability to stimulate plant immunity, reducing plant pathogen infection [16]. Based on their antimicrobial properties, it could be suggested that microbial biosurfactants can be exploited for phytopathogen control.

In medicine, lipopeptides have received the utmost attention owing to their high surface activity and antibiotic potential, which aid their applications as antibiotics, antitumor agents, and immunomodulators [17-19]. Lipopeptides have strong activity against multidrug-resistant bacteria, like Escherichia coli and Staphylococcus aureus [20]. Additionally, the studied antibacterial and biofilm disruption properties of biosurfactants (rhamnolipids and sophorolipids) for E. coli NCTC 10418 showed their ability to attach to surfaces, and they inhibit microbial growth and the resulting biofilm formation [21]. Iturin is a well-known lipopeptide biosurfactant reported to have antimicrobial activity [22]. Structurally, it is a cyclic peptide of seven amino acids linked to a fatty acid ( $\beta$-amino) chain that can vary in length from C-14 to C-17 carbon molecules. These molecules increase iturin's potency for plasma membrane disruption and increase the electrical conductance of biomolecular lipid membranes [23]. Therefore, iturin has been proposed as an antifungal agent in medicine. Additionally, fengycin, a lipopeptide containing a peptide chain of 10 amino acids linked to a fatty acid chain [24], has been reported as an antifungal agent [25].

The immunomodulatory activities of biosurfactants in mammals [17,26,27], Caenorhabditis elegans [28], and plants [29] have been investigated. More specifically, certain bacterial lipopeptides have been shown to be potent non-toxic, non-pyrogenic immunological adjuvants when mixed with conventional antigens [30]. For example, low-molecular-weight antigen iturin AL, herbicolin $\mathrm{A}$, and microcystin coupled with poy-L-lysine enhance the humoral immune response in rabbits and chickens [17]. Additionally, emulsan has been approved for use as an adjuvant owing to its immunomodulatory potential in the human body.

In the mammalian innate and adaptive immune systems, conserved bacterial and viral components are detected by pattern recognition receptors. Specifically in humans, toll-like receptors have been identified as receptors for signals generated by lipopolysaccharides (LPS) and lipoproteins/lipopeptides (LPs/LPTs) to activate the immune response [31]. Conversely, the activation of insect immune-related genes begins when pathogen-associated molecular patterns (PAMPs) are recognized by germ-line-encoded receptors and soluble proteins [32]. PAMPs are conserved molecules on bacterial or fungal cell walls and include peptidoglycans (PGNs) on Gram-positive or Gram-negative bacteria and $\beta$-1,3-glucans on fungi [32]. Therefore, in insects, the lysine-containing PGN from Gram-positive bacteria and $\beta$-1,3-glucans from fungi are recognized by peptidoglycan recognition proteins (PGRPs) and Gram-negative binding protein (GNBP), respectively [33-35]. In general, the recognition of these proteins leads to the activation of serine protease cascades, including modular serine protease (MSP), Spätzle-processing enzyme-activating enzyme (SAE), and Spätzle-processing enzyme (SPE) [36,37], and eventually results in the cleavage of prospätzle. Finally, the processed spätzle binds to toll-like receptors, which play a key role in the insect immune response [36].

The recognition of these molecules by PGRPs or GNBP is selectively based on their structure. For instance, structurally, PGNs consist of carbohydrate chains connected to $\beta$ (1-4), $\mathrm{N}$-acetylglucosamine, and $\mathrm{N}$-acetylmuramic acid sugars cross-linked by short peptide chains with alternating L- and D-amino acids [38]. Interestingly, D-amino acids are also recognized by receptors and 
enzymes in mammals to provide either a direct toxic response or indirect actions through modulating antimicrobial peptides [39]. Lipopeptides, the most commonly known biosurfactants, also consist of lipids connected to a peptide backbone containing a mix of L- and D-amino acids [40]. Additionally, rhamnolipids, one of the well-studied glycolipids, are composed of one or more monosaccharide moieties bound by a glycosidic linkage to a hydrophobic moiety [41]. Considering their peptide or sugar backbone compositions, lipopeptides and glycolipids are supposed to induce the innate immune response. Based on these reports of biosurfactant applications in plants and animals, it can be said that biosurfactants have both antimicrobial and immune-eliciting properties. However, the biosurfactant-triggered defense response in insects is yet to be studied.

Therefore, in this study, the induction of TmSpatzle by lipopeptides (fengycin and iturin A), polypeptide (bacitracin), and glycolipid (rhamnolipid) was studied. To the best of our knowledge, this is the first report indicating that lipopeptides (fengycin and iturin A) and glycolipids (rhaminolipds) increase the survivability of the mealworm Tenebrio molitor by activating different antimicrobial peptides through the activation of TmSpz4, TmSpz6, TmSpz3, or TmSpz-like in T. molitor.

\section{Results}

\subsection{AMP Activity in the Hemolymph of Biosurfactant-Injected T. molitor Larvae}

To determine the in vitro AMP activity against Gram-positive and Gram-negative bacteria and fungi, the hemolymph of biosurfactant-immune activated larvae was mixed with E. coli, S. aureus, and C. albicans. All the tested biosurfactants significantly $(p<0.05)$ reduced the growth of $E$. coli compared with PBS (Figure 1). Conversely, there was no difference between the control group (PBS) and biosurfactants group regarding growth of Gram-positive bacteria and fungi (Figure 1).

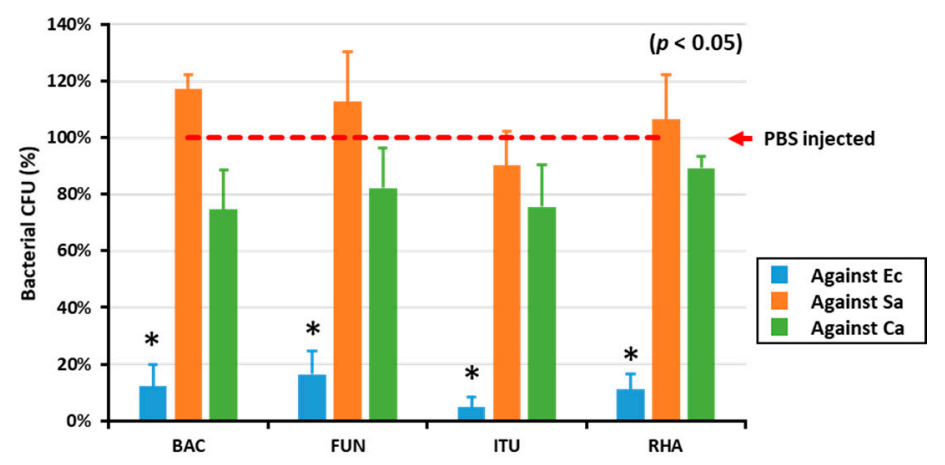

Figure 1. The in vitro AMP activity of biosurfactant-immune activated larvae against microbes. The in vitro AMP activities of biosurfactant-immune activated larvae against Gram-positive (S. aureus, Sa), Gram-negative bacteria (E. coli, Ec), and fungi (C. albicans, Ca) were measured by mixing the hemolymph of immune-activated larvae and the microbes. Excitingly, the results revealed that all the tested biosurfactants including bacitracin (BAC), fengycin (FUN), iturin A (ITU), and rhamnolipid (RHA) significantly $(p<0.05)$ reduced E. coli growth, compared with the PBS-injected control group (red dotted line).* significant difference $(p<0.05)$ of CFU, compared to the PBS-injected group.

\subsection{Biosurfactants Induced AMP Expression in T. molitor Hemocytes}

To further understand how E. coli growth was inhibited by the hemolymph of biosurfactant-immune activated T. molitor larvae, the AMP expression level was assessed after injecting biosurfactants into T. molitor larvae. RNA was extracted $24 \mathrm{~h}$ post injection, and qRT-PCR was conducted using T. molitor AMP-specific primers. All tested biosurfactants induced different types of AMPs in hemocytes (Figure 2A,B,D). Particularly, iturin A upregulated the expressions of TmTen-1 (4-fold), TmTen-3 (14.67-fold), TmTen-4 (15.72-fold), TmAtt-1b (14.49-fold), TmCol-1 (6-fold), TmDef-1 (12-fold), and TmDef-2 (10-fold) (Figure 2C). Similarly, bacitracin (TmTen-3, TmDef-1, and TmDef-2), fengycin (TmTen-2, TmTen-4, and TmAtt-1a) (Figure 2B), and rhamnolipids (TmTen-1, TmTen-2, TmTen-3, TmTen-4, 
TmDef-1, and TmDef-2) slightly upregulated the expression of AMPs (Figure 2D). In hemocytes, TmTen-3, $T m D e f-1$, and TmDef-2 were upregulated by all tested biosurfactants, excluding fengycin. Likewise, TmTen-2 was upregulated only by fengycin and rhamnolipids, while TmAtt-1b was upregulated by iturin A and fengycin. Conversely, in the fat bodies, most of the AMPs were either downregulated or remained constant like those of the control group. In the gut, except bacitracin and iturin $\mathrm{A}$, which remarkably downregulated AMPs, the expressions of almost all the AMPs were similar to the control.
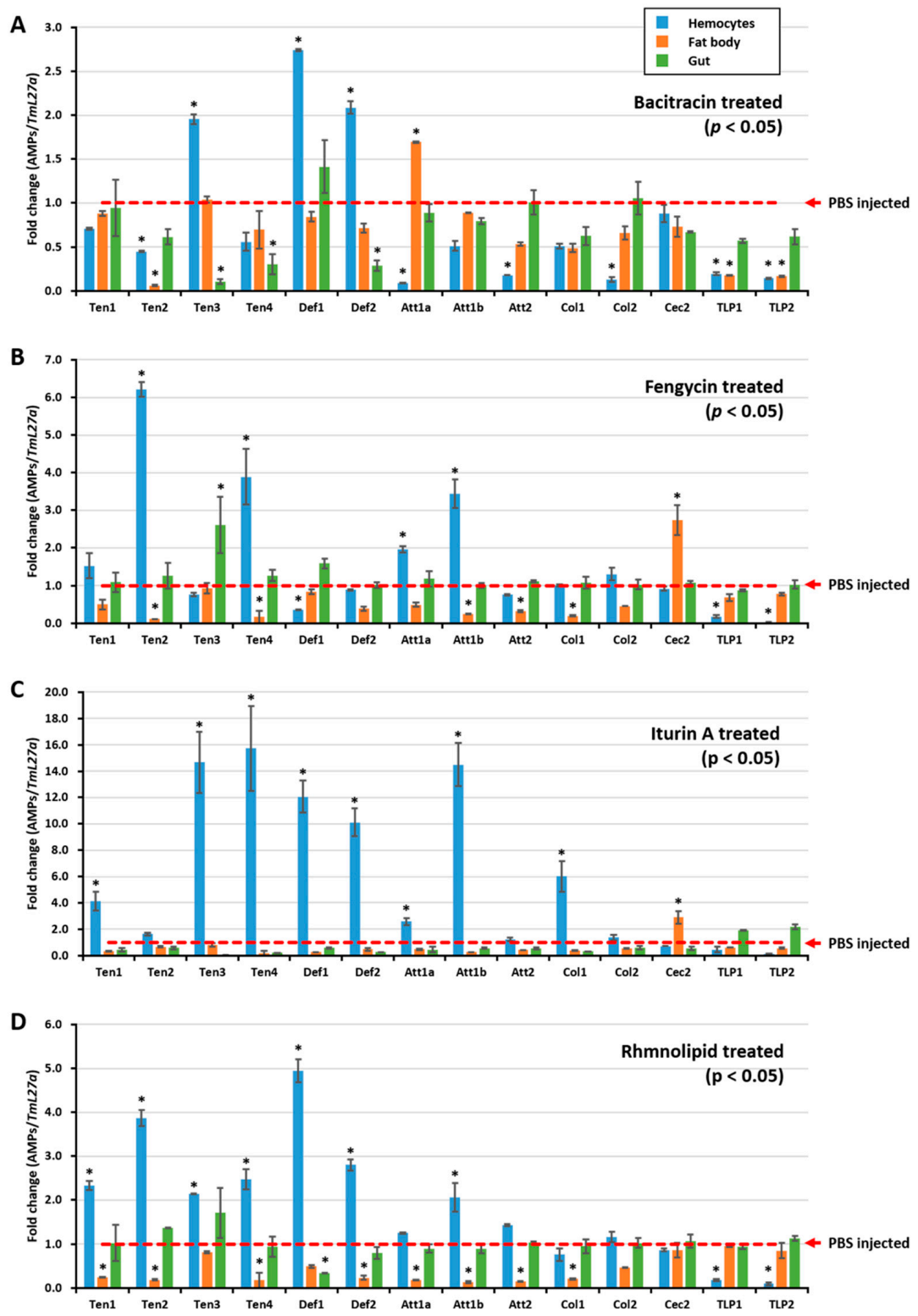

Figure 2. Biosurfactant-induced expression of antimicrobial peptides in T. molitor. The AMP expression levels were assessed $24 \mathrm{~h}$ after injecting either bacitracin (A), fengycin (B), itiurin A (C), or rhamnolipid (D) into T. molitor larvae. Three tissues—-hemocytes, fat body, and gut-were then dissected. The expression of AMPs in each tissue was quantified by qRT-PCR, using specific primers. The expression results are presented as mean of three replicates. ${ }^{*}$ significant difference $(p<0.05)$ in AMP expression, compared to the PBS-injected group. The AMP expression results revealed that all tested biosurfactants induced different types of AMPs in hemocytes. 


\subsection{Biosurfactants Increased T. molitor Larvae Survivability against E. coli}

To confirm if biosurfactant-activated AMPs could increase survivability against E. coli, a T. molitor larvae survivability assay was conducted by challenging the insect with E. coli $\left(10^{6} \mathrm{CFU} / \mu \mathrm{L}\right)$ at 0,12 , and $24 \mathrm{~h}$ post immune activation by biosurfactants. Interestingly, fengycin, iturin $\mathrm{A}$, and rhamnolipids significantly $(p<0.05)$ increased the survivability in $24 \mathrm{~h}$ post immune activated groups (Figure 3 ). Fengycin, iturin A, and rhamnolipids increased survivability against E. coli by 33.72, 34.48, and 28.75\%, respectively. However, larvae challenged by E. coli at both 0 and $12 \mathrm{~h}$ post immune activation by biosurfactant did not show significant survivability when compared with the control group. This may suggest that AMP expression was regulated $24 \mathrm{~h}$ post biosurfactant-immune activation. Thus, survivability results confirm the AMP expression observed in this study.
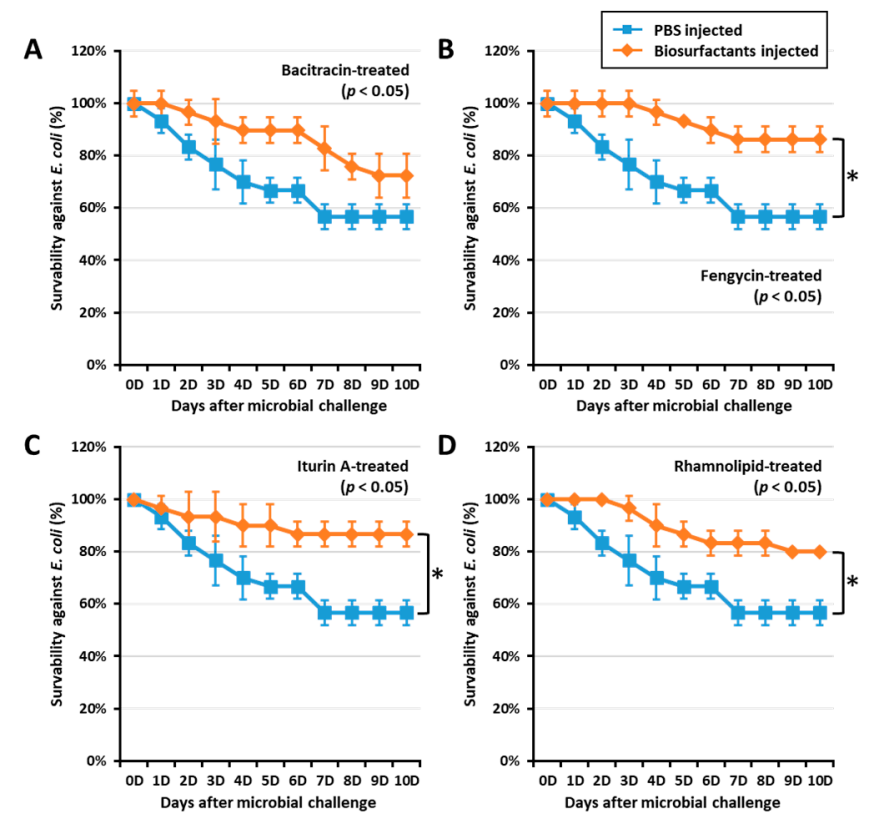

Figure 3. Effect of biosurfactants on T. molitor larvae survivability against E. coli. T. molitor larvae survivability against $E$. coli was assessed by challenging with $E$. coli $\left(10^{6} \mathrm{CFU} / \mu \mathrm{L}\right) 24 \mathrm{~h}$ post immune activation by biosurfactants such as bacitracin (A), fengycin (B), iturin A (C), and rhamnolipid (D). Interestingly, fengycin, iturin A, and rhamnolipid significantly increased the survivability against E. coli by $33.72,34.48$, and $28.75 \%$, respectively. The graph indicated by asterisks ${ }^{*}$ ) shows significant difference at $p<0.05$ following the Student-Newman-Keuls test.

\subsection{Biosurfactants Activated the Expression of Spätzle Genes in T. molitor}

To understand if biosurfactants induce AMP expression via the activation of spätzle genes in T. molitor, biosurfactant-induced activation of T. molitor spätzle was first examined and screened. The results revealed that TmSpz3 and TmSpz-like were upregulated in hemocytes by iturin A, while TmSpz 4 and TmSpz 6 were upregulated in the fat bodies by fengycin, iturin A, and rhamnolipids (Figure 4). The other spatzles remained constant or downregulated, compared to the PBS-injected group. In the bacitracin-injected larvae, no spätzle was significantly upregulated. Comparatively, higher fold changes in TmSpz4 and TmSpz6 expressions were observed in rhamnolipid-injected groups. 
A
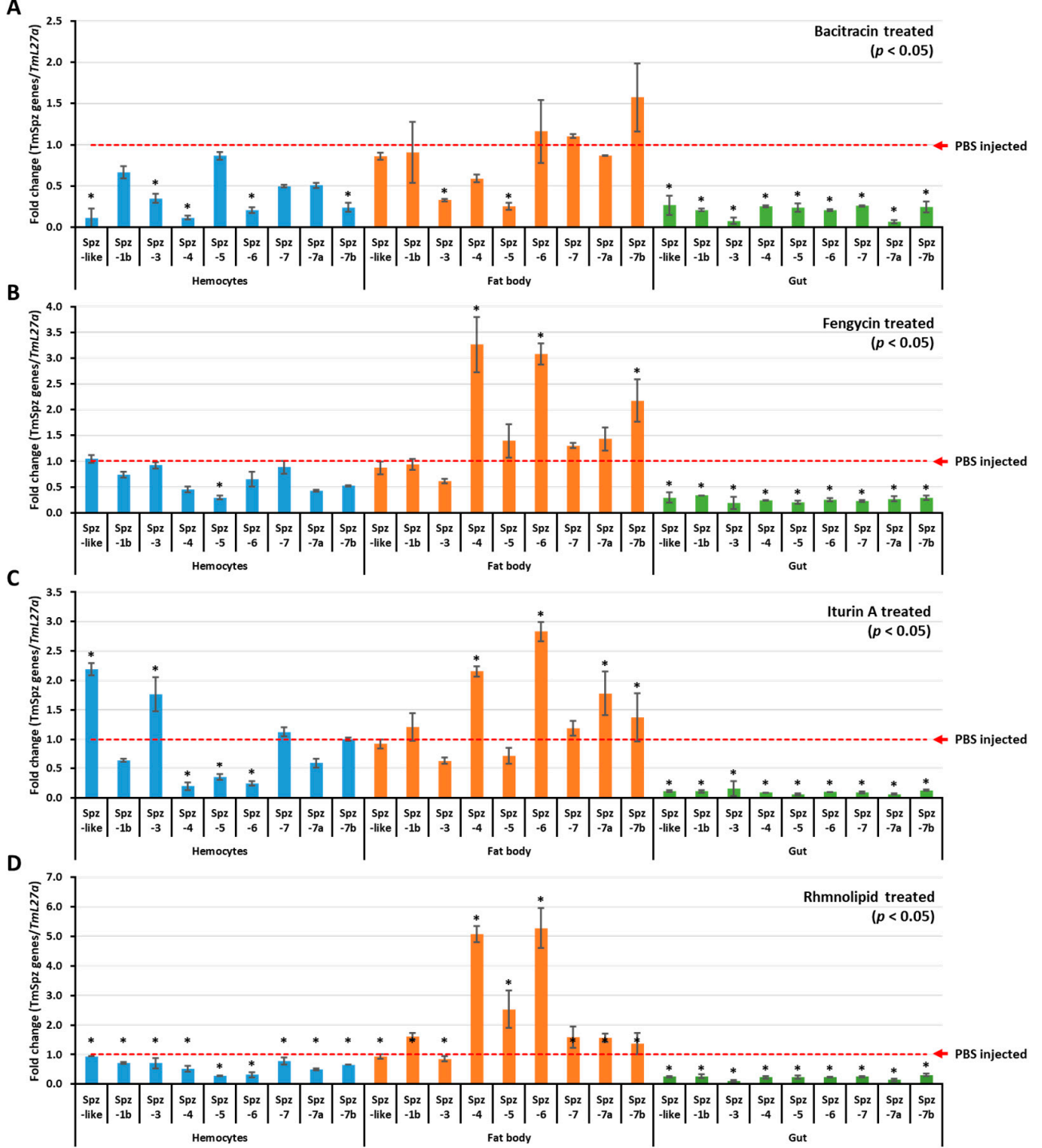

Figure 4. TmSpzs induction patterns in different tissues. The expressions of Spatzles gene in different tissues were examined by injecting either bacitracin (A), fengycin (B), iturin A (C), or rhamnolipid (D). Twenty-four hours post biosurfactant injection, three tissues-hemocytes, fat bodies, and gut-were dissected. The expression of spätzle in each tissue was quantified by qRT-PCR using specific primers. The data are the average of three replicates. * significant difference $(p<0.05)$ of Spatzles expression, compared to the PBS-injected group.

\subsection{Effect of TmSpz Gene Silencing on the Expression of AMPs in T. molitor}

To study whether activated spatzles have a role in biosurfactant-induced AMP expression in T. molitor, the screened spätzle genes (TmSpz3, TmSpz4, TmSpz6, and TmSpz-like) were silenced. Then, we checked and confirmed the gene silencing levels of TmSpz3 (Figure 5A), TmSpz-like (Figure 5C), TmSpz4 (Figure 6A), and TmSpz6 (Figure 7A). The biosurfactants were then injected into the gene-silenced larvae, respectively. The quantification of AMP expression showed that TmSpz3, TmSpz4, TmSpz6, and TmSpz-like positively regulated the expression of most of the AMPs in the whole body. Specifically, the expressions of TmTen-2, -4, TmAtt-1a, TmAtt-1b, TmAtt-2, TmCol-1, and TmCol-2 were significantly downregulated in the TmSpz3-silenced and iturin A-injected larvae (Figure 5B). The expressions of TmTen-2, TmCol-1, and -2 were positively regulated by TmSpz-like (Figure 5D). 

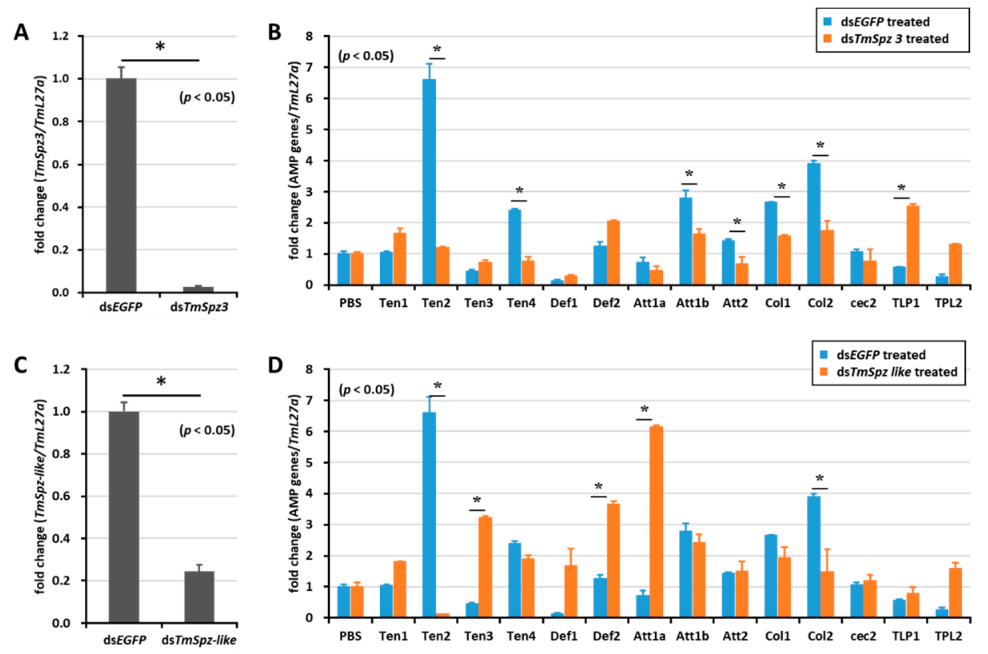

Figure 5. Induction of AMPs after gene silencing of TmSpz-3 and -like and injection of iturin A. The expressions of TmSpz3 (A) and TmSpzlike (C) were silenced, and iturin A was injected into the gene-silenced larvae. AMP expression was then examined in T. molitor, in the dsTmSpz3 (B), and dsTmSpz-like (D)-injected larvae. The expression of AMPs was quantified by qRT-PCR, using specific primers. * indicates significant difference $(p<0.05)$ of AMPs expression, compared to the dsEGFP-injected group.
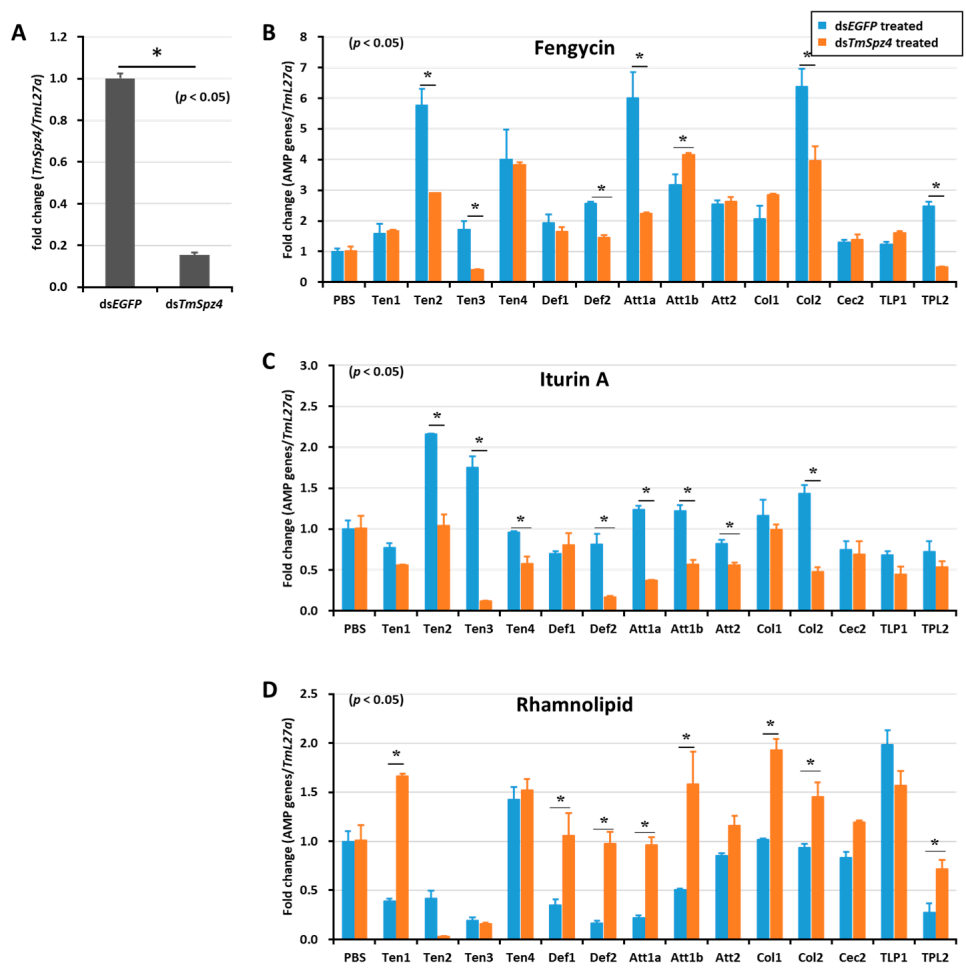

Figure 6. Effect of TmSpz 4 gene silencing on AMP induction in T. molitor larvae. The expression of TmSpz 4 was silenced (A), then either fengycin (B), iturin A (C), or rhamnolipid (D) was injected into the gene-silenced larvae. Whole-body AMP expression was examined after $9 \mathrm{~h}$ post biosurfactant injection. The expression of AMPs in each tissue was quantified by qRT-PCR, using specific primers. The data are the mean of three individual replicates. * significant difference $(p<0.05)$ in AMP expression, compared to the dsEGFP-injected group. 

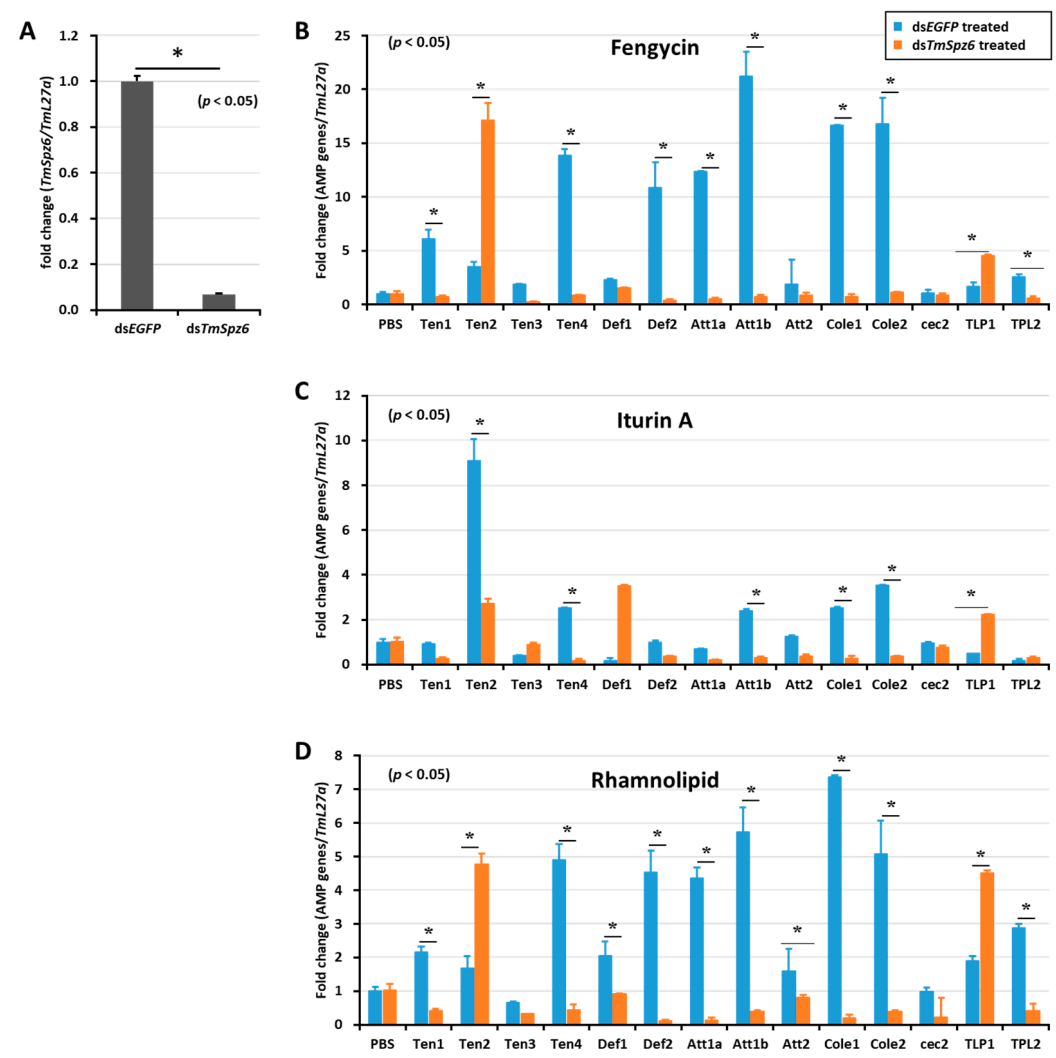

Figure 7. Effect of TmSpz 6 gene silencing on AMP induction in T. molitor larvae. TmSpz 6 expression was silenced (A), then either fengycin (B), iturin A (C), or rhamnolipid (D) was injected into the gene-silenced larvae. Whole-body AMP expression was examined after $9 \mathrm{~h}$ post biosurfactant injection. The expression of AMPs in each tissue was quantified by qRT-PCR, using specific primers. The data are the mean of three individual replicates. * significant difference $(p<0.05)$ in AMP expression, compared to the dsEGFP-injected group.

Likewise, TmSpz4 knock-down remarkably reduced the expression of AMPs induced by fengycin (TmTen-2, TmTen-3, TmTen-4, TmAtt-1a, TmCol-2, and TmDef-2) (Figure 6B) and iturin A (TmTen-2, TmTen-3, TmTen-4, TmDef-2, TmAtt-1a, TmAtt-1b, TmAtt-2, and TmCol-2) (Figure 6C) in the whole body. The expressions of most of the AMPs induced by rhamnolipid were negatively regulated by TmSpz4 in (Figure 6D).

The deletion of TmSpz6 resulted in a significant $(p<0.05)$ reduction in the AMP expression induced by fengycin (TmTen-1, TmTen-4, TmDef-2, TmAtt-1a, TmAtt-1b, TmCol-1, and TmCol-2) (Figure 7B), iturin A (TmTen-2, TmTen-4, TmAtt-1b, TmCol-1, and TmCol-2) (Figure 7C), and rhamnolipid (TmTen-1, TmTen-4, TmDef-1, TmDef-2, TmAtt-1a, TmAtt-1b, TmCol-1, TmCol-2, and TLP-2) (Figure 7D).

\subsection{T. molitor Larvae Survivability Study}

To further understand if the biosurfactants increased the survivability of T. molitor via spätzle gene activation and AMP induction against microbial challenge, TmSpzs were individually silenced (Figure 8A,C, Figures 9A and 10A), and each biosurfactant was injected into the gene-silenced larvae. Next, $24 \mathrm{~h}$ post biosurfactant injection, E. coli was injected. The results revealed that in the TmSpz3 and -like gene-silenced larvae, iturin A injection did not increase the survivability of larvae against $E$. coli infection, whereas in the dsEGFP injected larval group (control), iturin A significantly increased the survivability (Figure 8B,D). Meanwhile, fengycin and iturin A increased the survivability of larvae injected with dsEGFP, while TmSpz4 gene-silenced larvae were susceptible to E. coli (Figure 9B,C). Conversely, rhamnolipid showed no significant induction of larval survivability among the TmSpz4 gene-silenced and dsEGFP-injected larvae (Figure 9D). Similarly, although fengycin and rhamnolipid 
significantly $(p<0.05)$ increased control group survivability, the dsTmSpz6-injected larvae were susceptible to E. coli (Figure 10B-D).
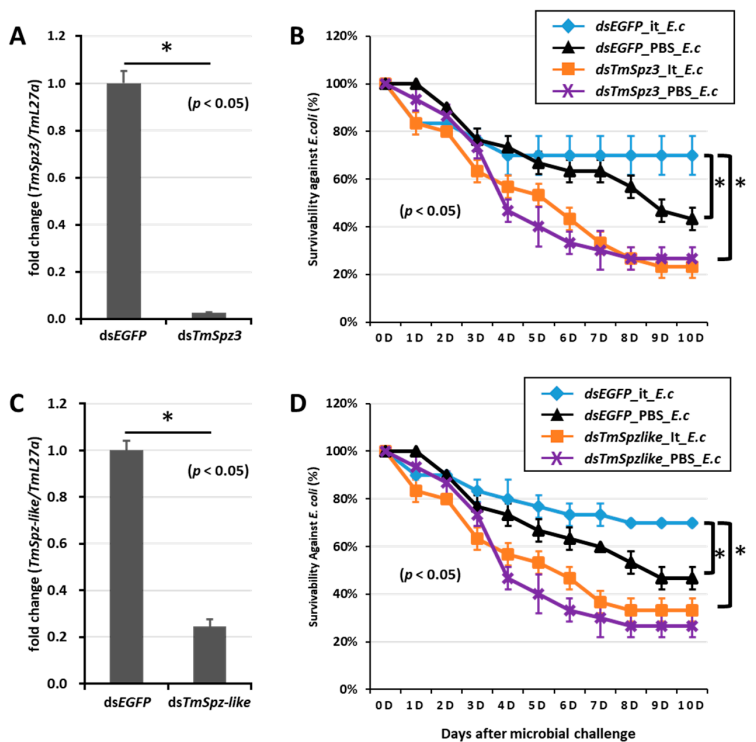

Figure 8. Survivability of T. molitor larvae against E. coli after TmSpz-3 or -like gene silencing and iturin A injection. The TmSpz-3 or -like gene were silenced, and the silencing efficiency was measured by qRT-PCR at $3 \mathrm{~d}$ post-injection (A,C). Iturin A (It) was then injected into the TmSpz-3 (B) and -like (D) gene-silenced larvae. After $24 \mathrm{~h}$ of iturin A injection, E. coli (E.c) was injected into the gene-silenced larvae. dsEGFP and 1XPBS were injected as control for gene and iturin A- or microbe-injected groups, respectively. The data represent the mean of three biological replicate experiments. ${ }^{*}$ significant differences between dsTmSpz-3, -like, and dsEGFP-treated and PBS-injected larval groups $(p<0.05)$.
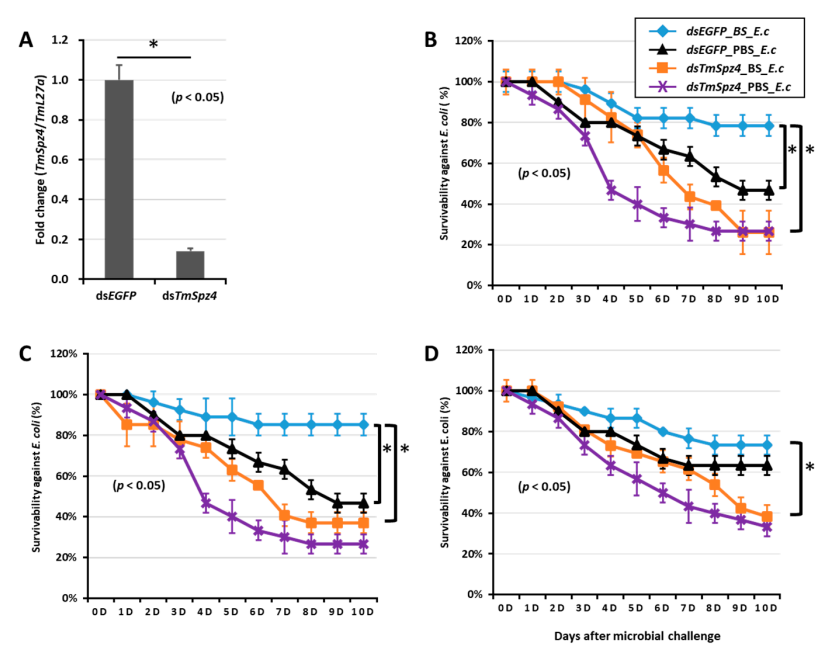

Figure 9. Survivability of T. molitor larvae against E. coli (E.c) after TmSpz4 gene silencing and biosurfactant injection. The TmSpz4 gene was silenced, and the silencing efficiency of TmSpz4 mRNA was measured by qRT-PCR at $5 \mathrm{~d}$ post-injection (A). Then, biosurfactants (BS) including fengycin (B), iturin A (C), and rhamnolipid (D) were separately injected into the gene-silenced larvae. E. coli was then injected into the gene-silenced and biosurfactant-injected larvae. dsEGFP and 1XPBS were injected as control for the gene- and biosurfactant- or microbe-injected groups, respectively. The data represent the mean of three biological replicate experiments. * significant differences between dsTmSpz4- and dsEGFP-treated groups of biosurfactant- and PBS-injected larvae $(p<0.05)$. 

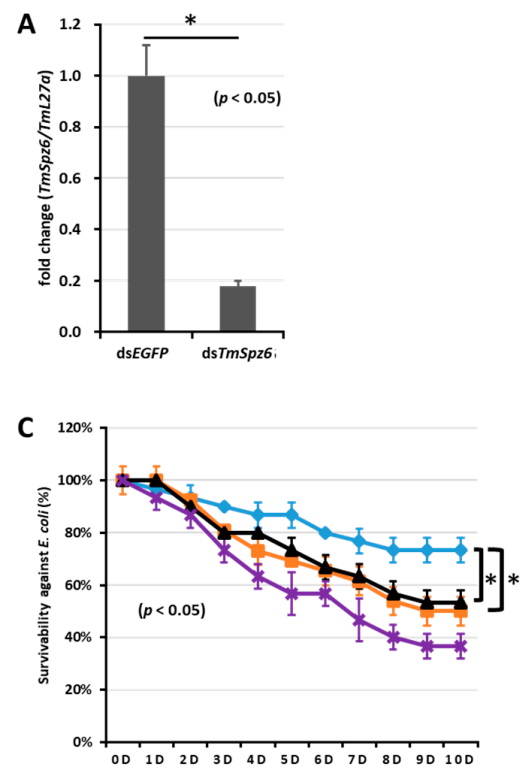
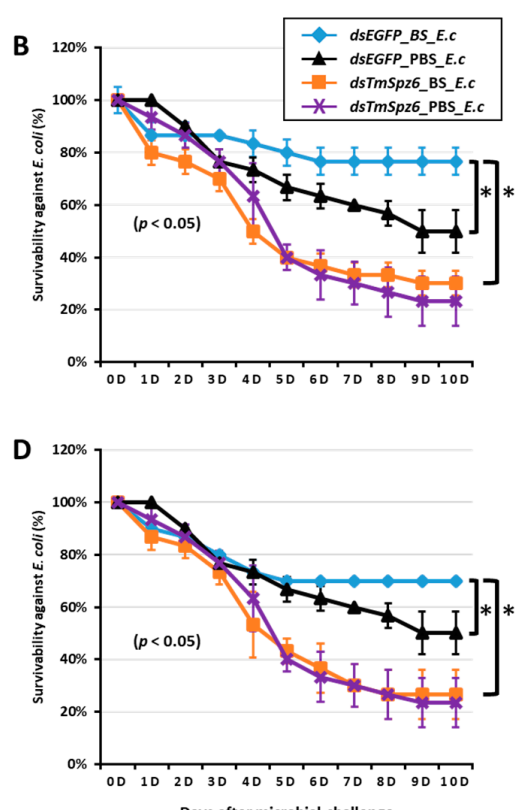

Figure 10. Survivability of T. molitor larvae against E. coli (E.c) after TmSpz6 gene silencing and biosurfactant injection. The TmSpz 6 gene was silenced, and the silencing efficiency of TmSpz 6 mRNA was measured by qRT-PCR at 3 d post-injection (A). Then, biosurfactants (BS) including fengycin (B), iturin A (C), and rhamnolipid (D) were separately injected into gene-silenced larvae. E. coli was then injected to the gene-silenced- and biosurfactant-injected larvae. dsEGFP and 1XPBS were injected as control for the gene- and biosurfactant- or microbe-injected groups, respectively. The data represent the mean of three biological replicate experiments. * significant differences between dsTmSpz6- and dsEGFP-treated groups, biosurfactant-, and PBS-injected larvae $(p<0.05)$.

\section{Discussion}

Biosurfactants have been repeatedly shown to exhibit antimicrobial activity [42-44]. In addition, the immune response modulators of biosurfactants have been investigated in mammalian and nematode C. elegans [26-28]. Therefore, based on the immunomodulatory reports, it could be hypothesized that biosurfactants could activate the immune response of T. molitor against microorganisms. Thus, to test this postulation, the in vitro growth inhibitions of Gram-positive and Gram-negative bacteria and fungi were performed by mixing microbial cells with the hemolymph of biosurfactant-immune activated larvae. Excitingly, the results revealed that all the tested biosurfactants significantly reduced the CFU of the Gram-negative bacteria E. coli, with no difference observed between the control and biosurfactants against Gram-positive bacteria and fungi. These results suggest that the tested biosurfactants specifically inhibit the growth of Gram-negative bacteria via activating the production of AMPs in T. molitor hemolymph.

In insects, AMPs are constitutively produced in fat bodies and hemocytes and are then released into the hemolymph in response to infection or immune elicitors after the recognition PAMPs [45-47]. In T. molitor, the identified AMPs include tenecins (-1, -2, -3, -4) [48-50], attacins [51], defensins [52], and coleopterins [53]. In general, AMPs are known to act against Gram-positive and -negative bacteria and fungi $[48,54,55]$ by membrane disruption, interference with bacterial metabolism, and targeting of cytoplasmic components $[47,56,57]$. Therefore, based on our in vitro results, it could be suggested that biosurfactants induce the production of active AMPs against E. coli. Interestingly, besides their antimicrobial properties, biosurfactants have the ability to elicit mealworm immune responses against microorganisms.

The inhibition of E. coli CFU by the hemolymph of biosurfactant-immune triggered T. molitor larvae was a call for concern. As explained earlier, AMPs form the main immune response produced during infection or immune elicitation. Therefore, AMP expression levels were determined by injecting 
biosurfactants into T. molitor larvae. Various AMPs were induced by the injection of biosurfactants, suggesting that biosurfactants could regulate the innate immunity of T. molitor through the induction of AMPs in hemocytes. However, using a different mechanism, B. licheniformis-derived [58] and rhamnolipid biosurfactants [59] have also demonstrated the ability for modulation of immune responses in Labeo rohita. Moreover, rhamnolipid displayed immunostimulatory properties against human monocyte cells by improving the secretion of the cytokine tumor necrosis factor [60].

The major concern here is how the host recognizes these lipopetides or glycolipids to activate the immune response. Even though the known pattern recognition receptors of D-amino acids have not been identified, D-amino acids are asymmetrically recognized by some other receptors and enzymes in mammals to provide either direct toxic responses or indirect actions through the modulation of antimicrobial peptides [39]. Additionally, Li Hao and his colleagues described that the presence of D-amino acids in the peptide structure can play a key role in mammalian receptor recognition [61]. Based on the composition of the different L- and D-amino acids, including D-amino acids (Tyr, Orn, and Thr, Ala) in fengycin and the D-amino acids (Tyr, Asn, and Asn) of the cyclic lipopeptide iturin A [62], the recognition of these biosurfactants could be attributable to certain recognition receptors that activate AMPs.

Toll receptors have been identified and known to recognize evolutionarily conserved bacterial components such as LPS, LP, LPT, and PGN in mammals [31,63]. Moreover, it has been reported that CD14 facilitates LP recognition by toll-like receptors 2 and 1 in humans [64-66]. Similarly, LPS binding protein (LBP) is a serum factor known to have the ability to bind pathogens and initiate the innate immune response [67]. Moreover, it has been reported that LP could enhance TLR2-mediated activation, a promising strategy for vaccine development [68].

Contrarily, in insects, during both embryogenesis and immunity, inactive spätzle protein is synthesized and secreted from the cell, containing a pro domain and a C-terminal region $[69,70]$. During infection, microbe-associated molecular patterns, such as LPS and lipoteichoic acid (LTA), are recognized by PGN recognition protein and GNBP1 [33], leading to the initiation of the proteolytic cascade, serine protease, and SPE [36]. Therefore, this process finally activates the initially inactive spätzle. Extrapolating to the mammalian and insect immune activation systems, the bacillus LP (fengycin and iturin A) and glycolipid (rhamnolipid) are found activating the TmSpatzle genes in T. molitor. It should be noticed that the recognition receptor for these specific biosurfactants is not well known.

The effect of biosurfactants in the survivability of the T. molitor Spätzle gene-silenced group was examined, and the TmSpz gene-silenced larvae showed susceptibility to E. coli, while the control group larvae significantly survived. This indicates that the biosurfactant-induced immune response occurs via the activation of TmSpz genes. Most of the AMPs suppressed in the absence of spätzle genes including TmSpz4 (TmTen-2, TmAtt-1a, and TmCol-2), TmSpz3 (TmTen-2, TmTen-4, TmAtt-1b, TmCol-1, and TmCol-2), and TmSpz6 (TmTen-2, TmTen-4, TmDef-2, TmAtt-1a, TmAtt-1b, TmCol-1, and TmCol-2) are the well-known AMPs active against Gram-negative bacteria [48,71,72]. Most glycine-rich AMPs are highly specific and effective against groups of Gram-negative bacteria [73]. Supporting our current survivability and AMP expression study results, attacins in Hyalophora cecropia [74], TmTen-4 in T. molitor [48], and TmTen-2 in T. molitor [71], which are glycine-rich AMPs, have been reported as being particularly effective against Gram-negative bacteria [71]. Similarly, in our recent publication we have reported TmSpz6 is important in regulating the AMPs production in response to E. coli [75]. Therefore, it can be said that the biosurfactant-activated AMPs enable larvae to be protected against E. coli. Altogether, our results revealed that LP and glycolipid biosurfactants induce AMP expression in T. molitor through spätzle gene activation, thereby increasing T. molitor larvae survivability against E. coli. 


\section{Materials and Methods}

\subsection{Insect Culture}

The coleopteran insect mealworm, Tenebrio molitor, was maintained at $27 \pm 1{ }^{\circ} \mathrm{C}, 60 \% \pm 5 \%$ relative humidity, under dark conditions, with an artificial diet (170 $\mathrm{g}$ of whole-wheat flour, $20 \mathrm{~g}$ of fried bean powder, $10 \mathrm{~g}$ of soy protein, $100 \mathrm{~g}$ of wheat bran, $200 \mathrm{~mL}$ of sterile water, $0.5 \mathrm{~g}$ of chloramphenicol, $0.5 \mathrm{~g}$ of sorbic acid, and $0.5 \mathrm{~mL}$ of propionic acid). Larvae at the 10 th to 12 th instar were used for experiments [76].

\subsection{Source of Biosurfactants}

The biosurfactants (bacitracin, fengycin, iturin A, and rhamnolipids) used in this study were purchased from Sigma Aldrich (St. Louis, MO, USA) (Table 1). All the biosurfactants were in powder form.

Table 1. List of biosurfactants, their types, and their biological sources.

\begin{tabular}{ccccc}
\hline Biosurfactants. & Type & Biological Source & Type & Purity \\
\hline Bacitracin & cyclic lipopeptide & Bacillus licheniformis & Gram-positive & $90 \%$ \\
Fengycin & lipopeptide complex & Bacillus subtilis & Gram-positive & $>90 \%$ \\
Iturin A & cyclic lipopeptide & Bacillus subtilis & Gram-positive & $>95 \%$ \\
Rhamnolipid & Glycolipids & Pseudomonas aeruginosa & Gram-negative & $>95 \%$ \\
\hline
\end{tabular}

\subsection{Preparation of Microorganisms}

Gram-negative bacteria (E. coli K12), Gram-positive bacteria (S. aureus RN4220), and fungi (Candida albicans) were used in this study. These microorganisms were cultured in Luria-Bertani (LB; E. coli and S. aureus) and Sabouraud dextrose (C. albicans) broths at $37^{\circ} \mathrm{C}$ overnight, subcultured at $37^{\circ} \mathrm{C}$ for $3 \mathrm{~h}$. Then, the microorganisms were harvested and washed two times by centrifugation at $3500 \mathrm{rpm}$ for $10 \mathrm{~min}$ in phosphate-buffered saline (PBS; pH 7.0). They were then suspended in PBS, and their concentrations were measured at OD600. Finally, $10^{6}$ cells $/ \mu \mathrm{L}$ of E. coli, S. aureus, and $5 \times 10^{4}$ cells $/ \mu \mathrm{L}$ of C. albicans were injected separately [77].

\subsection{AMPs Activity Study}

Each biosurfactant was dissolved by vortexing in the $1 x$ PBS at $1 \mu \mathrm{g} / \mu \mathrm{L}$ (biosurfactant/PBS). Then, the stock solution of each biosurfactant was diluted to the targeted concentration (100, 200, 300, and $1000 \mathrm{ng} / \mu \mathrm{L}$ ). Late instars larvae of T. molitor were injected with $300 \mathrm{ng} / \mu \mathrm{L}$ of each biosurfactant. During each injection, the solution was well vortexed to insure uniform distribution of the particle. This concentration was selected based on the previous preliminary experiment. Briefly, we conducted the preliminary experiment with 100, 200, 300, and $1000 \mathrm{ng} / \mu \mathrm{L}$ biosurfactants injection, and the highest AMPs activity was achieved at $300 \mathrm{ng} / \mu \mathrm{L}$. 1X PBS (0.1 mM sodium phosphate, $2.5 \mathrm{mM}$ potassium chloride, $\mathrm{pH}$ 7.2) was injected as control. The injections were done using disposable needles mounted onto a micro applicator (Picospiritzer III micro dispense system, Parker Hannifin, Hollis, NH). The injected larvae were maintained on artificial diet under standard rearing conditions. Twenty-four hours post injection, the hemolymph was extracted in to 1X PBS on ice. Then, the hemolymph was centrifuged at $15,000 \mathrm{rpm}$ and $4{ }^{\circ} \mathrm{C}$ for $10 \mathrm{~min}$. The supernatant was retrieved and boiled at $100{ }^{\circ} \mathrm{C}$ for $10 \mathrm{~min}$, then centrifuged at $15,000 \mathrm{rpm}$ and $4{ }^{\circ} \mathrm{C}$ for $10 \mathrm{~min}$, and then the supernatant transferred to a new tube. Finally, peptide concentration was determined by Ephoch at OD220. The hemolymph sample was diluted by $1 X$ PBS and $100 \mu \mathrm{g}$ mixed with E. coli $\left(10^{6} \mathrm{CFU}\right)$. The total $200 \mu \mathrm{L}$ mixture (10 $\mu \mathrm{L}$ hemolymph sample, $10 \mu \mathrm{L}$ E. coli, and $180 \mu \mathrm{L}$ PBS) was incubated at $37^{\circ} \mathrm{C}$ for $1 \mathrm{~h}$ under shaking conditions (200 rpm). Then, $10^{-5}$ serial dilution was done, and $100 \mu \mathrm{L}$ of the mixture was plated on LB agar media and incubated at $37^{\circ} \mathrm{C}$ for $16 \mathrm{~h}$. The assay was done in triplicate for each biosurfactant, and the colony per plate for each biosurfactant was counted. 


\subsection{RNA Extraction, cDNA Synthesis, and Expression of AMPs}

Each biosurfactant was injected at $300 \mathrm{ng} / \mu \mathrm{L}$ in to late larvae of T. molitor. 1X PBS was injected into the control group larvae. Twenty-four hours after biosurfactant injection, the whole-body samples from 20 larvae were injected with each biosurfactant to $500 \mu \mathrm{L}$ of guanidine thiocyanate RNA lysis buffer, which was prepared from 0.5 M EDTA, 1 M MES buffer, 3 M guanidine thiocyanate, $200 \mathrm{mM}$ sodium chloride, phenol red $(40 \mu \mathrm{L}), 25 \mu \mathrm{L}$ of Tween-80, $250 \mu \mathrm{L}$ of acetic acid glacial (for $\mathrm{pH} 5.5$ ), and $500 \mu \mathrm{L}$ of isoamyl alcohol. Samples were homogenized using a homogenizer machine (Bertin Technologies, France) for $20 \mathrm{~s}$. RNA extraction was done following the protocol [76].

Expression patterns of fourteen AMPs-TmTencin-1 (TmTen-1), TmTencin-2 (TmTen-2), TmTencin-3 (TmTen-3), TmTencin-4 (TmTen-4), TmAttacin-1a (TmAtt1a), TmAttacin-1b (TmAtt-1b), TmAttacin-2 (TmAtt-2), TmDefensin-1 (TmDef-1), TmDefensin-2 (TmDef-2), TmColptericin-1 (TmCol-1), TmColptericin-2 (TmCol-2), TmCecropin-2 (TmCec-2), TmThaumatin like protein-1 (TmTLP-1), and TmThaumatin like protein-2 (TmTLP-2) — were investigated by quantitative real-time polymerase chain reaction (qRT-PCR) using specific primers (Table 2), with AccuPower ${ }^{\circledR}$ Greenstar $^{\mathrm{TM}}$ qPCR PreMix (Bioneer, Daejeon, Korea) and the AriaMx Real-Time PCR System (Agilent Technologies, USA). The qRT-PCR conditions were as follows: pre-denaturation at $95^{\circ} \mathrm{C}$ for $5 \mathrm{~min}$, followed by 40 cycles of denaturation at $95^{\circ} \mathrm{C}$ for $15 \mathrm{~s}$, and annealing and extension at $60^{\circ} \mathrm{C}$ for $30 \mathrm{~s}$. Primers designed from T. molitor ribosomal protein L27a (TmL27a) were used as internal control.

Table 2. Primers used in this study.

\begin{tabular}{|c|c|}
\hline Name & Primer Sequences \\
\hline TmTencin-1_Fw & 5'-CAGCTGAAGAAATCGAACAAGG-3' \\
\hline TmTencin-1_Rv & 5'-CAGACCCTCTTTCCGTTACAGT-3' \\
\hline TmTencin-2_Fw & 5'-CAGCAAAACGGAGGATGGTC-3' \\
\hline TmTencin-2_Rv & 5'-CGTTGAAATCGTGATCTTGTCC-3' \\
\hline TmTencin-3_Fw & 5'-GATTTGCTTGATTCTGGTGGTC-3' \\
\hline TmTencin-3_Rv & 5'-CTGATGGCCTCCTAAATGTCC-3' \\
\hline TmTencin-4_Fw & 5'-GGACATTGAAGATCCAGGAAAG-3' \\
\hline TmTencin-4_Rv & 5'-CGGTGTTCCTTATGTAGAGCTG-3' \\
\hline TmDefensin-1_Fw & 5'-AAATCGAACAAGGCCAACAC-3' \\
\hline TmDefencin-1_Rv & 5'-GCAAATGCAGACCCTCTTTC-3' \\
\hline TmDefencin-2_Fw & 5'-GGGATGCCTCATGAAGATGTAG-3' \\
\hline TmDefencin-2_Rv & 5'-CCAATGCAAACACATTCGTC-3' \\
\hline TmColoptericin-1_Fw & 5'-GGACAGAATGGTGGATGGTC-3' \\
\hline TmColoptericin-1_Rv & 5'-CTCСAACATTCCAGGTAGGC-3 \\
\hline TmColoptericin-2_Fw & 5'-GGACGGTTCTGATCTTCTTGAT-3' \\
\hline TmColoptericin-2_Rv & 5'-CAGCTGTTTGTTTGTTCTCGTC-3' \\
\hline TmAttacin-1a_Fw & 5'-GAAACGAAATGGAAGGTGGA-3' \\
\hline TmAttacin-1a_Rv & 5'-TGCTTCGGCAGACAATACAG-3' \\
\hline TmAttacin-1b_Fw & 5'-GAGCTGTGAATGCAGGACAA-3' \\
\hline TmAttacin-1b_Rv & 5'-CССТСТGATGAAACСТCCAA-3' \\
\hline TmAttacin-2_Fw & 5'-AACTGGGATATTCGCACGTC-3' \\
\hline TmAttacin-2_Rv & 5'-CCCTCCGAAATGTCTGTTGT-3 \\
\hline TmCecropin-2_Fw & 5'-TACTAGCAGCGCCAAAACCT-3' \\
\hline TmCecropin-2_Rv & 5'-CTGGAACATTAGGCGGAGAA-3' \\
\hline TmThaumatin-like protein-1_Fw & 5'-CTCAAAGGACACGCAGGACT-3' \\
\hline TmThaumatin-like protein-1_Rv & 5'-ACTTTGAGCTTCTCGGGACA-3' \\
\hline
\end{tabular}


Table 2. Cont.

\begin{tabular}{|c|c|}
\hline Name & Primer Sequences \\
\hline TmThaumatin-like protein-2_Fw & 5'-CCGTCTGGCTAGGAGTTCTG-3' \\
\hline TmThaumatin-like protein-2_Rv & 5'-ACTCСТCСАGCTCCGTTACA-3' \\
\hline TmL27a_qPCR_Fw & 5'-TCATCCTGAAGGCAAAGCTCCAGT-3' \\
\hline TmL27a_qPCR_Rv & 5'-AGGTTGGTTAGGCAGGCACCTTTA-3' \\
\hline TmSpz4-qPCR-Fw & 5'-GGCGATGCTCTTCCAGGAC-3' \\
\hline TmSpz4-qPCR-Rv & 5'-CGCGTTCACTCCTTTCATTTGG-3' \\
\hline \multirow{2}{*}{ TmSpz4-T7-Fw } & 5'-TAATACGACTCACTATAGGGT \\
\hline & CCAGATGTACTGTCGCGATG-3' \\
\hline \multirow{2}{*}{ TmSpz4-T7-Rv } & 5'-TAATACGACTCACTATAGGGT \\
\hline & TTCCTTCTGTACCAGTCGGG-3' \\
\hline TmSpz6-qPCR-Fw & 5'-GCACAACTCCAAGACGACCT-3' \\
\hline TmSpz6-qPCR-Rv & 5'-TCTCTTCACCCGATCGTTGC-3' \\
\hline \multirow{2}{*}{ TmSpz6-T7-Fw } & 5'-TAATACGACTCACTATAGGGT \\
\hline & ACCGCGCAAGAGAGTAAAAA-3' \\
\hline \multirow{2}{*}{ TmSpz6-T7-Rv } & $5^{\prime}$-TAATACGACTCACTATAGGGT \\
\hline & ACGTATCTCCACACCCCTTG-3' \\
\hline TmSpz3-qPCR-Fw & 5'-TCTCAACAACGGGACCTTCG-3' \\
\hline TmSpz3-qPCR-Rv & 5'-GGGACGCCCCGTATGTATTC-3' \\
\hline \multirow{2}{*}{ TmSPZ3-T7-270bp-Fw } & 5'-TAATACGACTCACTATAGGGT \\
\hline & CGAGAACAAGGCACTGATGA-3' \\
\hline \multirow{2}{*}{ TmSPZ3-T7-270bp-Rv } & 5'-TAATACGACTCACTATAGGGT \\
\hline & GCGGTGCCATTTGTACTTCT-3' \\
\hline TmSPZ-like-qPCR-Fw & 5'-CAGTTGAGGGTGCCTGTTCA-3' \\
\hline TmSPZ-like-qPCR-Rv & 5'-TTGTTGGCATCGTCCCTTGA-3' \\
\hline \multirow{2}{*}{ TmSpz-like-T7-Fw } & 5'-TAATACGACTCACTATAGGGT \\
\hline & ATGTTCCCAAAATCAACGGA-3' \\
\hline \multirow{2}{*}{ TmSpz-like-T7-Rv } & 5'-TAATACGACTCACTATAGGGT \\
\hline & AATCACACGCAGATCCTTCC-3' \\
\hline \multirow{2}{*}{ dsEGFP_Fw } & 5'-TAATACGACTCACTATAGGGT \\
\hline & C $\overline{\text { GTAAACGGCCACAAGTTC-3' }}$ \\
\hline \multirow{2}{*}{ dsEGFP_Rv } & 5'-TAATACGACTCACTATAGGGT \\
\hline & TGCTCAGGTAGTGTTGTCG-3' \\
\hline
\end{tabular}

\subsection{Biosurfactant-Triggered Immune Survivability of T. molitor}

Thirty young instars (9-12 instars) larvae of T. molitor were injected with $300 \mathrm{ng} / \mu \mathrm{L}$ of each biosurfactant, and 1X PBS as control. At different time points $(0,12$, and $24 \mathrm{~h})$ post injection, E. coli $\left(10^{6} \mathrm{CFU}\right)$ were injected in to the immune-triggered and PBS-injected larvae. In the $0 \mathrm{~h}$ group, biosurfactants and E. coli were injected at the same time. The experiment was performed in triplicate (10 larvae/replication). Mortality data were counted daily for $10 \mathrm{~d}$.

\subsection{Screening of Biosurfactant-Activated T. molitor Spatzle Genes}

Biosurfactants were injected in to T. molitor larvae, and $24 \mathrm{~h}$ post injection, three tissues-the hemocytes, fat bodies and guts-were dissected, RNA extracted, and cDNA synthesized following the abovementioned protocol. Using gene-specific primers, the expressions of nine T. molitor Spätzle genes following biosurfactant injection were analyzed. The expression was quantified by qRT-PCR. 


\subsection{Effect of Tm Spätzle Gene Silencing on the Expression of AMPS}

To synthesize the double-stranded RNA of the TmSpz genes, forward and reverse primers containing the T7 promoter sequence at their $5^{\prime}$ ends were designed using the SnapDragon-Long dsRNA design software (Harvard Medical School, Boston, MA, USA, https://www.flyrnai.org/cgibin/ RNAi_find_primers.pl). The PCR product was amplified using AccuPower ${ }^{\circledR}$ Pfu PCR PreMix with TmSpz_Fw and TmSpz_Rv under the following cycling conditions: an initial denaturation step at $94^{\circ} \mathrm{C}$ for $2 \mathrm{~min}$, followed by 35 cycles of denaturation at $94^{\circ} \mathrm{C}$ for $30 \mathrm{~s}$, annealing at $53^{\circ} \mathrm{C}$ for $30 \mathrm{~s}$, and extension at $72{ }^{\circ} \mathrm{C}$ for $30 \mathrm{~s}$, with a final extension step at $72{ }^{\circ} \mathrm{C}$ for $5 \mathrm{~min}$. The PCR products were purified using the AccuPrep PCR Purification Kit (Bioneer, Daejeon, Korea), and dsRNA was synthesized using the Ampliscribe ${ }^{\mathrm{TM}}$ T7-Flash ${ }^{\mathrm{TM}}$ Transcription Kit (Epicentre Biotechnologies, Madison, WI, USA), according to the manufacturer's instructions. After synthesis, the dsRNA was purified by precipitation with $5 \mathrm{M}$ ammonium acetate and $80 \%$ ethanol. Subsequently, it was quantified using an Epoch spectrophotometer (BioTek Instruments, Inc., Winooski, VT, USA). As a control, the dsRNA of enhanced green fluorescent protein $(\mathrm{dsEGFP})$ was synthesized, and all samples were stored at $-20^{\circ} \mathrm{C}$ until use.

To study whether the biosurfactants induced AMPs expression in T. molitor via the activation of Spätzle genes, TmSpz genes-those expressed by biosurfactants (T. molitor spätzle 3 (TmSpz3), spätzle 4 (TmSpz4), spätzle 6 (TmSpz6), and spätzle like (TmSpz-like))—were silenced by injecting the synthesized dsRNA ( $1 \mu \mathrm{g} / \mathrm{larvae})$ of each gene into the larvae hemocoel. dsEGFP was injected to a separate set of larvae that acted as negative control. The gene expression knockdown $(>85 \%)$ was achieved at $3 \mathrm{~d}$ (TmSpz3, TmSpz6, and TmSpz-like) and $5 \mathrm{~d}$ (TmSpz4) post injection of each dsRNA. The respective biosurfactants per specific day were then injected in the gene-silenced larvae. 1XPBS was injected as control group. Twenty-four hours post biosurfactant injection, RNA was extracted from the whole body. These time points were selected based on the preliminary experiment of AMP expression. Subsequently, cDNA synthesis was conducted following the previously described protocol. qRT-PCR was then conducted using specific primers to analyze the temporal expression patterns of the fourteen AMPs.

\subsection{Effect of TmSpz Genes Silencing on T. molitor Survivability}

The survivability study was investigated after the TmSpz3, TmSpz4, TmSpz6, and TmSpz-like genes were silenced. After gene silencing, the following biosurfactants were injected: iturin A in TmSpz3 and TmSpz-like gene-silenced larvae; fengycin, iturin, and bacitracin in TmSpz4 and TmSpz6 gene-silenced larvae. This grouping was based on the preliminary screening of TmSpz genes against biosurfactants. Twenty-four hours after biosurfactant injection, E. coli $\left(10^{6} \mathrm{CFU}\right)$ were injected in to the immune triggered larvae. The experiment was done in triplicate. Mortality data were counted daily for 10 days.

\subsection{Data Analyses}

The survivability data were subjected to analysis of variance (ANOVA) using SAS 9.4. Differences from the control were assessed using Tukey's multiple range test $(p<0.05)$. Comparative AMP gene expression was calculated using delta delta $C t(\Delta \Delta C t)$. The fold change from the internal control (TmL27a) and external control (PBS) was calculated using the formula $2^{-(\Delta \Delta C t)}$.

\section{Conclusions}

The antimicrobial properties of different biosurfactants from bacteria and fungi have been well studied. However, our current study revealed that fengycin and iturin A produced by Bacillus subtilis and rhamnolipids produced by Pseudomonas aeruginosa modulate the immunity of the yellow mealworm T. molitor. Generally, this study suggests that biosurfactants such as lipopeptides and glycolipids induce the expression of AMPs through activation of spätzle genes in hemocytes, thereby increasing the survivability of T. molitor larvae against $E$. coli (Figure 11). Based on our current results, these biosurfactants could be used as safe immune elicitors in the mass rearing of T. molitor. 


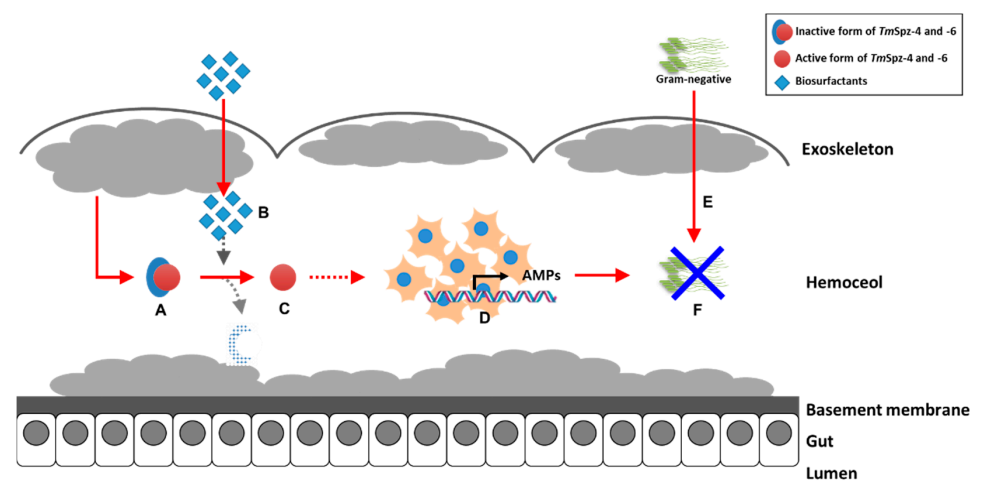

Figure 11. Proposed graphic summary of biosurfactants activity in the expression of AMPs through activation of TmSpz-4 and -6. The pro-form of TmSpzs (A) generated from fat body is activated by the injection of biosurfactants (B) to matured form of TmSpzs (C). The activated TmSpzs initiate the activation of intracellular toll signaling cascade in hemocytes to produce several AMPs (D), and when E. coli is injected into the T. molitor hemoceol (E), the produced AMPs protect the host from infection (F).

Author Contributions: Y.S.H. and Y.H.J. conceived and designed the experiments; Y.S.H., and Y.H.J. contributed reagents/materials/analysis tools; T.T.E. and M.K., performed the experiments; T.T.E. and Y.H.J., analyzed the data; T.T.E., wrote the first draft of the manuscript; T.T.E., Y.H.J. and Y.S.H., I.S.K. revised and edited the manuscript. All authors have read and agreed to the published version of the manuscript.

Funding: This research was supported by Basic Science Research Program through the National Research Foundation of Korea (NRF) funded by the Ministry of Science, ICT, and future Planning (Grant No. 2018R1A2A2A05023367).

Conflicts of Interest: The authors declare that the research was conducted in the absence of any commercial or financial relationships that could be construed as a potential conflict of interest.

\section{References}

1. Shekhar, S.; Sundaramanickam, A.; Balasubramanian, T. Biosurfactant producing microbes and their potential applications: A review. Crit. Rev. Environ. Sci. Technol. 2015, 45, 1522-1554. [CrossRef]

2. Vijayakuma, S.; Varatharajan, S. Biosurfactants-types, sources and applications. Res. J. Microbiol. 2015, 10, 181-192.

3. Edwards, J.R.; Hayashi, J.A. Structure of a rhamnolipid from pseudomonas aeruginosa. Arch. Biochem. Biophys. 1965, 111, 415-421. [CrossRef]

4. Asselineau, C.; Asselineau, J. Trehalose-containing glycolipids. Prog. Chem. Fats Other Lipids 1978, 16, 59-99. [CrossRef]

5. Gautam, K.K.; Tyagi, V.K. Microbial surfactants: A review. J.Oleo Sci. 2006, 55, 155-166. [CrossRef]

6. Chakrabarti, S. Bacterial Biosurfactant: Characterization, Antimicrobial and Metal Remediation Properties. Master's Thesis, National Institute of Technology, Rourkela, India, 2012.

7. Cavalero, D.A.; Cooper, D.G. The effect of medium composition on the structure and physical state of sophorolipids produced by candida bombicola atcc 22214. J. Biotechnol. 2003, 103, 31-41. [CrossRef]

8. Mohan, P.K.; Nakhla, G.; Yanful, E.K. Biokinetics of biodegradation of surfactants under aerobic, anoxic and anaerobic conditions. Water Res. 2006, 40, 533-540. [CrossRef]

9. Nitschke, M.; Costa, S.G.V.A.O. Biosurfactants in food industry. Trends Food Sci. Technol. 2007, 18, $252-259$. [CrossRef]

10. Singh, P.; Cameotra, S.S. Potential applications of microbial surfactants in biomedical sciences. Trends Biotechnol. 2004, 22, 142-146. [CrossRef]

11. Ongena, M.; Jacques, P. Bacillus lipopeptides: Versatile weapons for plant disease biocontrol. Trends Microbiol. 2008, 16, 115-125. [CrossRef]

12. Gordillo, A.; Maldonado, M.C. Purification of peptides from bacillus strains with biological activity. Chromatogr. Appl. 2012, 11, 201-225.

13. Gamalero, E.; Glick, B. Bacteria in Agrobiology: Plant Nutrient Management; Springer: New York, NY, USA, 2011; pp. 17-46. 
14. Velho, R.; Medina, L.; Segalin, J.; Brandelli, A. Production of lipopeptides among bacillus strains showing growth inhibition of phytopathogenic fungi. Folia Microbiol. 2011, 56, 297. [CrossRef] [PubMed]

15. Haddad, N.I.; Wang, J.; Mu, B. Isolation and characterization of a biosurfactant producing strain, brevibacilis brevis hob1. J. Ind. Microbiol. Biotechnol. 2008, 35, 1597-1604. [CrossRef] [PubMed]

16. Vatsa, P.; Sanchez, L.; Clement, C.; Baillieul, F.; Dorey, S. Rhamnolipid biosurfactants as new players in animal and plant defense against microbes. Int. J. Mol. Sci. 2010, 11, 5095-5108. [CrossRef] [PubMed]

17. Rodrigues, L.; Banat, I.M.; Teixeira, J.; Oliveira, R. Biosurfactants: Potential applications in medicine. J. Antimicrob. Chemother. 2006, 57, 609-618. [CrossRef]

18. Gudiña, E.J.; Rangarajan, V.; Sen, R.; Rodrigues, L.R. Potential therapeutic applications of biosurfactants. Trends Pharmacol. Sci. 2013, 34, 667-675. [CrossRef]

19. Gharaei-Fathabad, E. Biosurfactants in pharmaceutical industry: A mini-review. Am. J. Drug Discov. Dev. 2011, 1, 58-69.

20. Das, P.; Mukherjee, S.; Sen, R. Antimicrobial potential of a lipopeptide biosurfactant derived from a marine bacillus circulans. J. Appl. Microbiol. 2008, 104, 1675-1684. [CrossRef]

21. Díaz De Rienzo, M.A.; Stevenson, P.; Marchant, R.; Banat, I.M. Antibacterial properties of biosurfactants against selected gram-positive and -negative bacteria. FEMS Microbiol. Lett. 2015, 363, fnv224. [CrossRef]

22. Ahimou, F.; Jacques, P.; Deleu, M. Surfactin and iturin a effects on bacillus subtilis surface hydrophobicity. Enzym. Microb. Technol. 2000, 27, 749-754. [CrossRef]

23. Tsuge, K.; Akiyama, T.; Shoda, M. Cloning, sequencing, and characterization of the iturin a operon. J. Bacteriol. 2001, 183, 6265-6273. [CrossRef]

24. Akpa, E.; Jacques, P.; Wathelet, B.; Paquot, M.; Fuchs, R.; Budzikiewicz, H.; Thonart, P. Influence of culture conditions on lipopeptide production by bacillus subtilis. Appl. Biochem. Biotechnol. 2001, 91, 551-561. [CrossRef]

25. Deleu, M.; Paquot, M.; Nylander, T. Effect of fengycin, a lipopeptide produced by bacillus subtilis, on model biomembranes. Biophys. J. 2008, 94, 2667-2679. [CrossRef] [PubMed]

26. Sadeq Al-wazni, W. Immunomodulator activity of biosurfactant extract from serratia marcescens. Int. J. Microbiol. Res. 2016, 7, 36-42.

27. Gan, P.; Gao, Z.; Zhao, X.; Qi, G. Surfactin inducing mitochondria-dependent ros to activate mapks, $\mathrm{nf}-\mathrm{kb}$ and inflammasomes in macrophages for adjuvant activity. Sci. Rep. 2016, 6, 39303. [CrossRef] [PubMed]

28. Iatsenko, I.; Yim, J.J.; Schroeder, F.C.; Sommer, R.J.B. Subtilis gs67 protects c. Elegans from gram-positive pathogens via fengycin-mediated microbial antagonism. Curr. Biol. 2014, 24, 2720-2727. [CrossRef]

29. Van Wees, S.C.; Van der Ent, S.; Pieterse, C.M. Plant immune responses triggered by beneficial microbes. Curr. Opin. Plant Biol. 2008, 11, 443-448. [CrossRef]

30. Sil, J.; Dandapat, P.; Das, S. Health care applications of different biosurfactants. Int. J. Sci. Res. 2017, 6, 41-50.

31. Takeda, K.; Kaisho, T.; Akira, S. Toll-like receptors. Annu. Rev. Immunol. 2003, 21, 335-376. [CrossRef]

32. Medzhitov, R.; Janeway, C.A. Decoding the patterns of self and nonself by the innate immune system. Science 2002, 296, 298-300. [CrossRef]

33. Wang, L.; Weber, A.N.; Atilano, M.L.; Filipe, S.R.; Gay, N.J.; Ligoxygakis, P. Sensing of gram-positive bacteria in drosophila: Gnbp1 is needed to process and present peptidoglycan to pgrp-sa. EMBO J. 2006, 25, 5005-5014. [CrossRef] [PubMed]

34. Gobert, V.; Gottar, M.; Matskevich, A.A.; Rutschmann, S.; Royet, J.; Belvin, M.; Hoffmann, J.A.; Ferrandon, D. Dual activation of the drosophila toll pathway by two pattern recognition receptors. Science 2003, 302, 2126-2130. [CrossRef] [PubMed]

35. Roh, K.-B.; Kim, C.-H.; Lee, H.; Kwon, H.-M.; Park, J.-W.; Ryu, J.-H.; Kurokawa, K.; Ha, N.-C.; Lee, W.-J.; Lemaitre, B. Proteolytic cascade for the activation of the insect toll pathway induced by the fungal cell wall component. J. Biol. Chem. 2009, 284, 19474-19481. [CrossRef] [PubMed]

36. Jang, I.-H.; Chosa, N.; Kim, S.-H.; Nam, H.-J.; Lemaitre, B.; Ochiai, M.; Kambris, Z.; Brun, S.; Hashimoto, C.; Ashida, M. A spätzle-processing enzyme required for toll signaling activation in drosophila innate immunity. Dev. Cell 2006, 10, 45-55. [CrossRef]

37. Kim, C.-H.; Kim, S.-J.; Kan, H.; Kwon, H.-M.; Roh, K.-B.; Jiang, R.; Yang, Y.; Park, J.-W.; Lee, H.-H.; Ha, N.-C. A three-step proteolytic cascade mediates the activation of the peptidoglycan-induced toll pathway in an insect. J. Biol. Chem. 2008, 283, 7599-7607. [CrossRef] 
38. McDonald, C.; Inohara, N.; Nuñez, G. Peptidoglycan signaling in innate immunity and inflammatory disease. J. Biol. Chem. 2005, 280, 20177-20180. [CrossRef]

39. Sasabe, J.; Suzuki, M. Emerging role of d-amino acid metabolism in the innate defense. Front. Microbiol. 2018, 9, 9. [CrossRef]

40. Chen, Y.; Liu, S.A.; Mou, H.; Ma, Y.; Li, M.; Hu, X. Characterization of lipopeptide biosurfactants produced by bacillus licheniformis mb01 from marine sediments. Front. Microbiol. 2017, 8, 871. [CrossRef]

41. Abdel-Mawgoud, A.M.; Lépine, F.; Déziel, E. Rhamnolipids: Diversity of structures, microbial origins and roles. Appl. Microbiol. Biotechnol. 2010, 86, 1323-1336. [CrossRef]

42. Ndlovu, T.; Rautenbach, M.; Vosloo, J.A.; Khan, S.; Khan, W. Characterisation and antimicrobial activity of biosurfactant extracts produced by bacillus amyloliquefaciens and pseudomonas aeruginosa isolated from a wastewater treatment plant. AMB Express 2017, 7, 108. [CrossRef]

43. Abalos, A.; Pinazo, A.; Infante, M.; Casals, M.; Garcia, F.; Manresa, A. Physicochemical and antimicrobial properties of new rhamnolipids produced by pseudomonas a eruginosa at10 from soybean oil refinery wastes. Langmuir 2001, 17, 1367-1371. [CrossRef]

44. Chen, W.-C.; Juang, R.-S.; Wei, Y.-H. Applications of a lipopeptide biosurfactant, surfactin, produced by microorganisms. Biochem. Eng. J. 2015, 103, 158-169. [CrossRef]

45. Altincicek, B.; Vilcinskas, A. Metamorphosis and collagen-iv-fragments stimulate innate immune response in the greater wax moth, galleria mellonella. Dev. Comp. Immunol. 2006, 30, 1108-1118. [CrossRef] [PubMed]

46. Hwang, J.-S.; Lee, J.; Kim, Y.-J.; Bang, H.-S.; Yun, E.-Y.; Kim, S.-R.; Suh, H.-J.; Kang, B.-R.; Nam, S.-H.; Jeon, J.-P. Isolation and characterization of a defensin-like peptide (coprisin) from the dung beetle, copris tripartitus. Int. J. Pept. 2009, 2009, 136284. [CrossRef]

47. Jozefiak, A.; Engberg, R.M. Insect proteins as a potential source of antimicrobial peptides in livestock production. A review. J. Anim. Feed Sci. 2017, 26, 87-99. [CrossRef]

48. Chae, J.-H.; Kurokawa, K.; So, Y.-I.; Hwang, H.O.; Kim, M.-S.; Park, J.-W.; Jo, Y.-H.; Lee, Y.S.; Lee, B.L. Purification and characterization of tenecin 4, a new anti-gram-negative bacterial peptide, from the beetle tenebrio molitor. Dev. Comp. Immunol. 2012, 36, 540-546. [CrossRef]

49. Kim, D.-H.; Lee, Y.T.; Lee, Y.J.; Chung, J.H.; Lee, B.L.; Choi, B.S.; Lee, Y. Bacterial expression of tenecin 3, an insect antifungal protein isolated from tenebrio molitor, and its efficient purification. Mol. Cells (Springer Sci. Bus. Media BV) 1998, 8, 8 .

50. Lee, K.H.; Hong, S.Y.; Oh, J.E.; Kwon, M.y.; Yoon, J.H.; Lee, J.h.; Lee, B.L.; Moon, H.M. Identification and characterization of the antimicrobial peptide corresponding to c-terminal beta-sheet domain of tenecin 1 , an antibacterial protein of larvae of tenebrio molitor. Biochem. J. 1998, 334, 99. [CrossRef]

51. Dobson, A.J.; Johnston, P.R.; Vilcinskas, A.; Rolff, J. Identification of immunological expressed sequence tags in the mealworm beetle tenebrio molitor. J. Insect Physiol. 2012, 58, 1556-1561. [CrossRef]

52. Zhu, S. Discovery of six families of fungal defensin-like peptides provides insights into origin and evolution of the $\operatorname{cs} \alpha \beta$ defensins. Mol. Immunol. 2008, 45, 828-838. [CrossRef]

53. Zhu, J.-Y.; Wu, G.-X.; Zhang, Z. Upregulation of coleoptericin transcription in tenebrio molitor parasitized by scleroderma guani. J. Asia Pac. Entomol. 2014, 17, 339-342. [CrossRef]

54. Cheng, T.; Zhao, P.; Liu, C.; Xu, P.; Gao, Z.; Xia, Q.; Xiang, Z. Structures, regulatory regions, and inductive expression patterns of antimicrobial peptide genes in the silkworm bombyx mori. Genomics 2006, 87, 356-365. [CrossRef] [PubMed]

55. Rozgonyi, F.; Szabo, D.; Kocsis, B.; Ostorhazi, E.; Abbadessa, G.; Cassone, M.; Wade, J.; Otvos, L., Jr. The antibacterial effect of a proline-rich antibacterial peptide a3-apo. Curr. Med. Chem. 2009, 16, 3996-4002. [CrossRef] [PubMed]

56. Ongey, E.L.; Pflugmacher, S.; Neubauer, P. Bioinspired designs, molecular premise and tools for evaluating the ecological importance of antimicrobial peptides. Pharmaceuticals 2018, 11, 68. [CrossRef]

57. Patocka, J.; Nepovimova, E.; Klimova, B.; Wu, Q.; Kuca, K. Antimicrobial peptides: Amphibian host defense peptides. Curr. Med. Chem. 2019, 26, 5924-5946. [CrossRef]

58. Giri, S.S.; Sen, S.S.; Jun, J.W.; Sukumaran, V.; Park, S.C. Role of bacillus licheniformis vs16-derived biosurfactant in mediating immune responses in carp rohu and its application to the food industry. Front. Microbiol. 2017, 8, 514. [CrossRef]

59. Revathi, J.A. Immunostimulation by rhamnolipid biosurfactant from pseudomonas putida in labeo rohita. Int. J. Adv. Res. Biol. Sci. 2016, 3, 179-183. 
60. Bauer, J.; Brandenburg, K.; Zähringer, U.; Rademann, J. Chemical synthesis of a glycolipid library by a solid-phase strategy allows elucidation of the structural specificity of immunostimulation by rhamnolipids. Chem. Eur. J. 2006, 12, 7116-7124. [CrossRef]

61. Li, H.; Anuwongcharoen, N.; Malik, A.A.; Prachayasittikul, V.; Wikberg, J.E.S.; Nantasenamat, C. Roles of d-amino acids on the bioactivity of host defense peptides. Int. J. Mol. Sci. 2016, 17, 1023. [CrossRef]

62. Mondol, M.; Shin, H.; Islam, M. Diversity of secondary metabolites from marine bacillus species: Chemistry and biological activity. Mar. Drugs 2013, 11, 2846-2872. [CrossRef]

63. Ali Mohammadie Kojour, M.; Han, Y.S.; Jo, Y.H. An overview of insect innate immunity. Entomol. Res. 2020, 50, 282-291. [CrossRef]

64. Nakata, T.; Yasuda, M.; Fujita, M.; Kataoka, H.; Kiura, K.; Sano, H.; Shibata, K. Cd14 directly binds to triacylated lipopeptides and facilitates recognition of the lipopeptides by the receptor complex of toll-like receptors 2 and 1 without binding to the complex. Cell. Microbiol. 2006, 8, 1899-1909. [CrossRef] [PubMed]

65. Buwitt-Beckmann, U.; Heine, H.; Wiesmüller, K.-H.; Jung, G.; Brock, R.; Akira, S.; Ulmer, A.J. Tlr1-and tlr6-independent recognition of bacterial lipopeptides. J. Biol. Chem. 2006, 281, 9049-9057. [CrossRef] [PubMed]

66. Kang, J.Y.; Nan, X.; Jin, M.S.; Youn, S.-J.; Ryu, Y.H.; Mah, S.; Han, S.H.; Lee, H.; Paik, S.-G.; Lee, J.-O. Recognition of lipopeptide patterns by toll-like receptor 2-toll-like receptor 6 heterodimer. Immunity 2009, 31, 873-884. [CrossRef]

67. Wright, S.D.; Ramos, R.A.; Tobias, P.S.; Ulevitch, R.J.; Mathison, J.C. Cd14, a receptor for complexes of lipopolysaccharide (lps) and lps binding protein. Science 1990, 249, 1431-1433. [CrossRef]

68. Zaman, M.; Toth, I. Immunostimulation by synthetic lipopeptide-based vaccine candidates: Structure-activity relationships. Front. Immunol. 2013, 4, 318. [CrossRef]

69. Weber, A.N.; Gangloff, M.; Moncrieffe, M.C.; Hyvert, Y.; Imler, J.-L.; Gay, N.J. Role of the spätzle pro-domain in the generation of an active toll receptor ligand. J. Biol. Chem. 2007, 282, 13522-13531. [CrossRef]

70. Weber, A.N.; Tauszig-Delamasure, S.; Hoffmann, J.A.; Lelièvre, E.; Gascan, H.; Ray, K.P.; Morse, M.A.; Imler, J.-L.; Gay, N.J. Binding of the drosophila cytokine spätzle to toll is direct and establishes signaling. Nat. Immunol. 2003, 4, 794. [CrossRef]

71. Yu, Y.; Park, J.W.; Kwon, H.M.; Hwang, H.O.; Jang, I.H.; Masuda, A.; Kurokawa, K.; Nakayama, H.; Lee, W.J.; Dohmae, N.; et al. Diversity of innate immune recognition mechanism for bacterial polymeric meso-diaminopimelic acid-type peptidoglycan in insects. J. Biol. Chem. 2010, 285, 32937-32945. [CrossRef]

72. Jo, Y.H.; Park, S.; Park, K.B.; Noh, M.Y.; Cho, J.H.; Ko, H.J.; Kim, C.E.; Patnaik, B.B.; Kim, J.; Won, R. In silico identification, characterization and expression analysis of attacin gene family in response to bacterial and fungal pathogens in tenebrio molitor. Entomol. Res. 2018, 48, 45-54. [CrossRef]

73. Casteels, P.; Ampe, C.; Jacobs, F.; Tempst, P. Functional and chemical characterization of hymenoptaecin, an antibacterial polypeptide that is infection-inducible in the honeybee (apis mellifera). J. Biol. Chem. 1993, 268, 7044-7054. [PubMed]

74. Carlsson, A.; Engström, P.; Palva, E.T.; Bennich, H. Attacin, an antibacterial protein from hyalophora cecropia, inhibits synthesis of outer membrane proteins in escherichia coli by interfering with omp gene transcription. Infect. Immun. 1991, 59, 3040-3045. [CrossRef] [PubMed]

75. Edosa, T.T.; Jo, Y.H.; Keshavarz, M.; Bae, Y.M.; Kim, D.H.; Lee, Y.S.; Han, Y.S. Tmspz6 is essential for regulating the immune response to escherichia coli and staphylococcus aureus infection in tenebrio molitor. Insects 2020, 11, 105. [CrossRef] [PubMed]

76. Edosa, T.T.; Jo, Y.H.; Keshavarz, M.; Park, K.B.; Cho, J.H.; Bae, Y.M.; Kim, B.; Lee, Y.S.; Han, Y.S. Tmatg6 plays an important role in anti-microbial defense against listeria monocytogenes in the mealworm, tenebrio molitor. Int. J. Mol. Sci. 2020, 21, 1232. [CrossRef]

77. Keshavarz, M.; Jo, Y.H.; Park, K.B.; Ko, H.J.; Edosa, T.T.; Lee, Y.S.; Han, Y.S. Tm dorx2 positively regulates antimicrobial peptides in tenebrio molitor gut, fat body, and hemocytes in response to bacterial and fungal infection. Sci. Rep. 2019, 9, 1-19. [CrossRef]

(C) 2020 by the authors. Licensee MDPI, Basel, Switzerland. This article is an open access article distributed under the terms and conditions of the Creative Commons Attribution (CC BY) license (http://creativecommons.org/licenses/by/4.0/). 